\title{
Precautions in the intravenous use of iron-dextran
}

\author{
RAYMOND NEWCOMBE* \\ M.B., B.S., F.R.C.S. \\ Harrow Hospital, Harrow
}

\section{Introduction}

Increasing experience in the use of large doses of iron-dextran complex (Imferon) intravenously in the treatment of selected patients requiring parenteral iron has brought to light a number of points which ought to be considered in the choice of patients, and in the details of administration.

Intravenous iron-dextran has been mostly used in obstetrics and gynaecology. It is now being more widely used in other fields, and for this reason the author feels that his experience in a series of general medical and surgical patients is of value. Many of these were elderly and presented special problems not seen so clearly in the younger obstetrical patient.

The principle of giving a large dose of irondextran at one time to replace the iron deficit in iron deficiency anaemia carries advantages over a series of intramuscular or intravenous injections. Because of the low toxicity of the substance (Golberg, 1958) it is said there are no absolute contraindications. The most common method is to give diluted iron-dextran, in a concentration not exceeding $5 \%$ in normal saline, as an infusion over several hours. Direct injection of doses of between 20 and $50 \mathrm{ml}$ iron-dextran (equivalent of $1000-2500 \mathrm{mg}$ iron) has been introduced more recently.

\section{Methods}

The criteria for evidence of iron deficiency and indications for parenteral iron are described in a previous paper reporting the therapeutic results of a trial of total dose iron-dextran infusion (Newcombe, 1966). The amount of iron in milligrams required by each patient was calculated from the formula $0.3 \times$ weight in $\mathrm{lb} \times$ haemoglobin deficit in percentage. This amount is readily derived from tables supplied by the manufacturers of the irondextran complex used (Imferon).

Oral iron was discontinued at least 3 days before the infusion and the patients received no form of iron therapy subsequently, except in three patients who required blood transfusion and operation

\footnotetext{
*Present address: Maida Vale Hospital, London, W.9.
}

within 10 days of iron-dextran infusion because of unexpected renewed blood loss.

Two methods of administration were usedintravenous infusion of diluted iron-dextran and direct injection of large doses of concentrated iron-dextran.

For total dose infusion the calculated volume of iron-dextran was added aseptically to sterile normal saline to make a concentration not exceeding $5 \%$ iron-dextran. The infusions were given via plastic giving sets, using a small-bore polythene cannula, inserted into a vein in the upper limb. The solution was infused at 10 drops/min during the first $20 \mathrm{~min}$ and, no side effects being observed, the drip rate was then increased to $45 \mathrm{drops} / \mathrm{min}$ until the infusion was completed.

The author's technique for the direct injection of concentrated iron-dextran complex was as follows :

(1) An antihistamine, such as chlorpheniramine maleate (Piriton) $4 \mathrm{mg}$, was given orally $30 \mathrm{~min}$ before the test dose.

(2) A test dose of $0.5 \mathrm{ml}$ iron-dextran, diluted in $2 \mathrm{ml}$ of the patient's blood, was injected slowly. Reassurance was given that any flushed feeling would soon pass off.

(3) The patient was observed for $20 \mathrm{~min}$. At the end of that time the main dose was given by slow intravenous injection, diluted with an equal quantity of the patient's blood, at about $3 \mathrm{ml} / \mathrm{min}$. The patient was kept lying flat with no more than one pillow under the head during the injection and for 30 min afterwards.

Performed in this way, the injection proved no more difficult than that required for intravenous pyelography and, for reasons given below, would appear to be the best available method for the bedridden patient.

\section{Results}

The total dose infusion method was used for twenty-three patients and the direct injection technique was employed for a further twelve patients with various medical and surgical causes of iron deficiency. The average age of the first group was 60 years and of the second 64 years. It is not the 
purpose of this paper to discuss therapeutic response but this seemed adequate in both groups, haemoglobin rises of the order of $0.34-0.7 \mathrm{~g} / 100$ $\mathrm{ml} /$ week being obtained.

No severe systemic reactions were noted. Two patients, after total dose infusion, had mild pyrexia and headache and one had nausea. Transient nausea was noted on three occasions during direct injection.

Thrombophlebitis of the infusion vein was noted in five patients after total dose infusion. Three of these also developed deep calf vein thrombosis but this may have been related to factors other than the iron-dextran, such as confinement to bed. No such effects on the veins were noted after injection of concentrated iron-dextran. seem to be indicated in order to reduce systemic effects and the effects on the veins to a minimum.

\section{Systemic reactions}

Attention in the literature has been concentrated on the severe systemic reactions resembling shock and of an anaphylactoid nature in so far as there is a sudden onset. In all, there have been noted nineteen cases in 1446 patients in the published trials of total dose infusion (Table 1).

No severe reactions were observed in twentythree patients given iron-dextran by infusion or in twelve patients given direct injections of concentrated iron-dextran. A test dose was used on all occasions but none had to be excluded because of a reaction to the test dose. Intravenous iron-

TABLE 1

Incidence of severe reactions to iron-dextran total dose infusions in published trials

\begin{tabular}{|c|c|c|c|}
\hline Reference & No. of cases & Type of case & No. of severe systemic reactions \\
\hline Gartlan (1964) & 55 & Pregnancy anaemias & One acute hypersensitivity \\
\hline Clay et al. (1965) & $\begin{array}{r}128 \\
22\end{array}$ & $\begin{array}{l}\text { Pregnancy anaemias } \\
\text { Post-natal cases }\end{array}$ & $\begin{array}{l}\text { Seven pregnancy cases had anaphylactoid } \\
\text { or acute hypersensitivity reactions }\end{array}$ \\
\hline Frampton (1965) & 20 & $\begin{array}{l}\text { Obstetrical and } \\
\text { gynaecological }\end{array}$ & None \\
\hline $\begin{array}{l}\text { Goldthorp, Spencer } \\
\text { \& Dawson (1965) }\end{array}$ & 56 & Pregnancy anaemias & None \\
\hline Lane \& Scott (1965) & $\begin{array}{r}150 \\
50\end{array}$ & $\begin{array}{l}\text { Gynaecological } \\
\text { Obstetrical }\end{array}$ & $\begin{array}{l}\text { One anaphylacyoid-type in a } \\
\text { gynaecological patient }\end{array}$ \\
\hline Manson (1966) & 101 & Obstetrical & $\begin{array}{l}\text { Two anaphylactoid-type in puerperal } \\
\text { patients }\end{array}$ \\
\hline Basu (1965) & $\begin{array}{l}10 \\
10 \\
10\end{array}$ & $\begin{array}{l}\text { Ante-natal } \\
\text { Gynaecological } \\
\text { Puerperal }\end{array}$ & $\mathrm{C}^{2}$ \\
\hline Bonnar (1965) & $\begin{array}{r}50 \\
120 \\
80\end{array}$ & $\begin{array}{l}\text { Ante-natal } \\
\text { Post-abortion } \\
\text { Post-natal }\end{array}$ & $\begin{array}{l}\text { Three severe reactions in ante-natal } \\
\text { patients (two of these were } \\
\text { anaphylactoid or acute hypersensitivity) }\end{array}$ \\
\hline Smith (1965) & 18 & $\begin{array}{l}\text { Pregnant and non- } \\
\text { pregnant }\end{array}$ & None \\
\hline Yoffa (1965) & 16 & Surgical & None \\
\hline Varde (1964) & $\begin{array}{r}307 \\
29\end{array}$ & $\begin{array}{l}\text { Pregnancy anaemias } \\
\text { Gynaecological }\end{array}$ & One anaphylactoid-type reaction \\
\hline Malcolm (1966) & 12 & $\begin{array}{l}\text { Anaemias associated } \\
\text { with hepatosplenomegaly }\end{array}$ & None \\
\hline $\begin{array}{l}\text { Bhatt, Joshi \& Shah } \\
\text { (1966) }\end{array}$ & $\begin{array}{l}50 \\
26\end{array}$ & $\begin{array}{l}\text { Obstetrical } \\
\text { Gynaecological }\end{array}$ & $\begin{array}{l}\text { Three severe reactions in obstetrical } \\
\text { patients }\end{array}$ \\
\hline Newcombe (1966) & 21 & $\begin{array}{l}\text { Anaemias of varying } \\
\text { aetiology }\end{array}$ & None \\
\hline $\begin{array}{l}\text { Thaman \& Dogra } \\
\text { (1966) }\end{array}$ & 106 & Anaemic children & $\begin{array}{l}\text { One severe side effect including } \\
\text { bronchospasm }\end{array}$ \\
\hline
\end{tabular}

After infusion two patients with anaemia due to previous blood loss from the gastrointestinal tract had renewed haemorrhage within $48 \mathrm{hr}$. The significance of this in relation to the mild anticoagulant properties which iron-dextran appears to possess will be discussed, as well as the precautions which dextran was not employed during the series in two patients with an allergic diathesis.

It is assumed that these reactions have an allergic basis involving tissue immunity, although the only evidence available is the similarity of some of the reactions to anaphylactic shock. 
The precautions which have been recommended to avoid systemic reactions may be summarized as follows:

(1) Exclude patients with a strong allergic diathesis.

(2) Postpone administration in patients who have had an injection of any iron preparation between 7 and 21 days previously.

(3) Precede the infusion or injection by an antihistamine, for example, chlorpheniramine maleate: $4 \mathrm{mg}$ orally or intramuscularly.

(4) Employ a test dose. In an infusion the first few drops are given very slowly, and the drip is then continued at a slow rate (10 drops/min) for the first $20 \mathrm{~min}$, with the patient under close observation.

In direct injection of concentrated iron-dextran, a test dose is given $\frac{1}{2}-1 \mathrm{hr}$ beforehand as $0.5 \mathrm{ml}$ iron-dextran diluted in at least an equal quantity of the patient's blood and injected slowly.

It has been suggested (Lane, 1964) that in infusions the dilution of iron-dextran and a slow drip rate are important in avoiding systemic reactions. The absence of severe reactions to relatively rapid injection of large doses of concentrated irondextran (Dawson, Goldthorp \& Spencer, 1965), however, strongly suggests that these factors are not so important as has been thought.

A further point of confusion is that some of the authors of published trials who have been experienced in the infusion technique alone, have put some patients, in whom the chief symptom observed has been a transient flushing, into the severe reaction group (Clay et al., 1965). Peripheral vasodilatation is common on commencing direct injection of concentrated iron-dextran but soon passes off and is not of great consequence. Its effects are greatly mitigated by keeping the patient supine to avoid postural hypotension. The effect on blood pressure has been considered experimentally by Cox, King \& Reynolds (1965) and may be due to the small amount of loosely bound ferrous iron in iron-dextran complex.

\section{Effect on veins}

Thrombophlebitis after infusion is sometimes seen in the infusion vein, but not after direct injection (Dawson et al., 1965), and for this reason the latter technique may be preferred though the infusion method is the longer established.

Five of the author's cases given an infusion developed thrombophlebitis, but none after direct injection.

Thrombophlebitis is frequently seen after any prolonged infusion. Its incidence will be reduced if infusion time is confined to 4-5 hr.

There is good reason for using the direct in- jection method rather than infusion in the elderly bedridden subject. These patients are more liable to develop phlebothrombosis of the deep calf veins after a prolonged infusion. The author has had three cases of deep vein thrombosis following intravenous infusions associated with iron-dextran administration. All these infusions lasted more than $24 \mathrm{hr}$ and were in elderly subjects. Two had blood transfusions prior to iron-dextran infusion.

The intramuscular route is not suitable in the bedridden immobilized patient since these patients have a greatly reduced lymph flow and decreased absorption of iron-dextran from the muscle depots (Golberg, 1958). In addition, many of these patients are asthenic without much muscle mass. For these reasons the author prefers the direct injection technique in such patients.

\section{Effect on blood clotting}

Two of the author's cases being treated for iron deficiency anaemia following blood loss from lesions of the alimentary tract bled again within $48 \mathrm{hr}$ of iron-dextran infusion. This may have been coincidental, but iron-dextran does have a mild anticoagulant effect.

The effect of iron-dextran complex on blood clotting time by the Lee and White method has been studied by Golberg (1958). In vitro concentrations of iron-dextran less than the equivalent of $600 \mu \mathrm{g}$ of metallic iron per $100 \mathrm{ml}$ blood did not alter the clotting time beyond the normal range, whereas saccharated oxide of iron caused a linear rise in clotting time as the concentration increased, the normal upper limit for clotting being reached at $30 \mu \mathrm{g}$ of elemental iron per $100 \mathrm{ml}$. In rabbits, doses of iron-dextran up to $50 \mathrm{mg}$ of iron per $\mathrm{kg}$ were not observed to have significant effect on the clotting time.

In clinical practice, intravenous injections or infusions equivalent to $1000-3000 \mathrm{mg}$ of elemental iron are used. These yield peak serum iron levels in the range $24,000-95,000 \mu \mathrm{g} / 100 \mathrm{ml}$ (Marchasin \& Wallerstein, 1964). Levels of this order might be expected to affect blood coagulability and explain unexpected renewed blood loss.

The heparin retarded plasma clotting time by the method of Poller (1954) was investigated by the author in four patients in need of parenteral iron who received $25 \mathrm{ml}$ of iron-dextran $(1250 \mathrm{mg}$ iron) by direct intravenous injection over $10 \mathrm{~min}$. This showed an increase in clotting time which persisted $24 \mathrm{hr}$ after injection but which returned to normal by the 3 rd day and remained within normal limits thereafter (Table 2).

Circulating iron-dextran after large intravenous doses may, therefore, exert an anticoagulant effect of clinical importance, especially in the treatment 
TABLE 2

Effect of a single intravenous injection of $25 \mathrm{ml}$ iron-dextran (1250 $\mathrm{mg}$ iron) on heparin retarded plasma clotting time

\begin{tabular}{lccccc}
\hline & \multicolumn{5}{c}{ Heparin clotting time (min) } \\
\cline { 2 - 6 } Patient & $\begin{array}{c}\text { Before } \\
\text { injection }\end{array}$ & \multicolumn{4}{c}{ After injection } \\
\cline { 3 - 6 } & 1 day & 3 days & 8 days & 14 days \\
\hline $\begin{array}{c}\text { 1. Female, } \\
68 \text { years }\end{array}$ & 7.0 & 17.0 & 13.0 & 7.0 & 7.0 \\
$\begin{array}{c}\text { 2. Female, } \\
63 \text { years }\end{array}$ & 12.5 & 24.0 & 13.5 & 12.0 & 12.0 \\
$\begin{array}{c}\text { 3. Male, } \\
86 \text { years }\end{array}$ & 12.0 & 20.0 & 12.5 & 11.0 & 12.5 \\
$\begin{array}{c}\text { 4. Male, } \\
70 \text { years }\end{array}$ & 7.0 & 11.0 & 7.5 & 7.0 & 7.0 \\
\hline
\end{tabular}

of iron deficiency due to lesions causing persistent or intermittent blood loss. It seems prudent to avoid large intravenous doses of iron-dextran in patients with continuing acute blood loss. It is suggested that some time be allowed to elapse after gastrointestinal bleeding before giving irondextran in order to be reasonably certain that bleeding has ceased. Such a delay should not involve more than $48 \mathrm{hr}$, and will not significantly alter the response in terms of haemoglobin regeneration.

\section{Summary}

1. Precautions in the intravenous administration of large doses of iron-dextran complex are discussed in relation to a series of general medical and surgical patients, many of whom were elderly.

2. Systemic reactions were not a problem but it was thought important that the patient be kept supine during treatment.

3. The time of treatment should be kept short to avoid thrombophlebitis. Direct injection of concentrated iron-dextran was thought to be preferable to infusion in the elderly patient since it avoids restriction by an intravenous infusion for prolonged periods with risk of deep vein throm. bosis, as well as reducing or eliminating the problem of thrombophlebitis of the infusion vein.

4. Iron-dextran complex in high concentrations may have a mild anticoagulant effect. In cases of iron deficiency associated with blood loss the possibility of further bleeding being initiated by a large dose of iron-dextran should be considered.

\section{Acknowledgments}

I am grateful to the house physicians and house surgeons at Harrow Hospital, and to Mr P. Mills of Fisons Pharmaceuticals Ltd, for their assistance.

\section{References}

BASU, S.K. (1965) Administration of iron-dextran complex by continuous intravenous infusion. J. Obstet. Gynaec. Brit. Cwlth, 72, 253.

BhatT, R.V., Joshi, S.K. \& ShaH, M.C. (1966) Total dose intravenous infusion of iron-dextran (Imferon) in severe anaemia. Amer. J. Obstet. Gynec. 94, 1098.

BONNAR, J. (1965) Anaemia in obstetrics: an evaluation of treatment by iron-dextran infusion. Brit. med. J. ii, 1030.

Clay, B., Rosenberg, B., Sampson, N. \& Samuels, S.I. (1965) Reactions to total dose intravenous infusion of iron-dextran (Imferon). Brit. med. J. i, 29.

Cox, J.S.G., KING, R.E. \& ReYNoldS, G.F. (1965) Valency investigations of iron-dextran (Imferon). Nature (Lond.), 207, 1202.

Dawson, D.W., GoldthorP, W.O. \& SPencer, D. (1965) Parenteral iron therapy in pregnancy. J. Obstet. Gynaec. Brit. Cwlth, 72, 89.

Frampton, D.R. (1965) Reactions to intravenous irondextran. Brit. med. J. i, 316.

Gartlan, G.J. (1964) Parenteral iron in pregnancy. Brit. med. J. i, 435.

Golberg, L. (1958) Pharmacology of parenteral iron preparations. Iron in Clinical Medicine (Ed. by R. $O$. Wallerstein and S. R. Mettier), p. 74. University of California Press.

Goldthorp, W.O., Spencer, D. \& Dawson, D.W. (1965) Reactions to intravenous iron-dextran. Brit. med.J. i, 316.

LANE, R.S. (1964) Intravenous infusion of iron-dextran complex for iron-deficiency anaemia. Lancet, i, 852.

LANE, R.S. \& ScoTT, J.M. (1965) Reactions to intravenous iron-dextran. Brit. med. J. i, 449.

Malcolm, N. (1966) Iron dextran complex by total dose infusion in anaemia with hepatosplenic disorder. Trans. roy. Soc. trop. Med. Hyg. 60, 245.

Manson, I.W. (1966) Total dose infusions with iron-dextran complex in pregnancy and the puerperium. Med.J. Aust. i, 174.

Marchasin, S. \& Wallerstein, R.O. (1964) The treatment of iron-deficiency anaemia with intravenous iron-dextran. Blood, 23, 354.

NewCOMBE, R.L.G. (1966) Iron-dextran infusion: a clinical trial in surgical patients. J. therap. clin. Res. 1, 20.

Poller, L. (1954) Heparin-retarded plasma clotting test. Angiology, 5, 21.

SMITH, G.O. (1965) Imferon-total dose infusion technique. Med. J. Aust. i, 905.

Thaman, O.P. \& Dogra, K.N. (1966) Use of single-dose intravenous iron-dextran in children. Lancet, ii, 412.

VARDE, K.N. (1964) Treatment of 300 cases of iron deficiency of pregnancy by total dose infusion of iron-dextran complex. J. Obstet. Gynaec. Brit. Cwlth, 71, 919.

YofFA, D. (1965) Imferon-total dose infusion technique. Med. J. Aust. ii, 51. 